\title{
Vasudha Dalmia Being Hindu in India: culture, religion, and the Gita Press (1950)
}

The Gita Press has retained its reputation as the premier Hindu religious publishing concern of North India from its inception in 1926 up until the present day. Its Hindi monthly journal Kalyan - meaning 'propitious', 'blessed', 'beneficiary' was conceived at the same time and continues to enjoy an extensive circulation, with 200,000 current subscribers. ${ }^{1}$ The Press routinely brings out a substantial annual number of the journal, focusing on a particular issue or religious text. In January 1950, barely three years after independence, the Press published its voluminous special issue on Hindu Samskriti, or Hindu culture. This publication constituted a major political and cultural intervention in contemporary discourse that was to help shape the newly formed republic. The volume has had seven print runs since then and is still in print today, testifying to the power it continues to exert over vast sections of the North Indian reading public. ${ }^{2}$ Given the publishing history of the Press, which focuses on Hindu religious texts and moral tracts as drawing upon the authority of these texts, it is remarkable that the choice of focus in this annual issue was not on Hindu dharma, or Hindu religion, but on the more comprehensive 'Hindu culture'. In this chapter, I shall focus on the notion of religion as encased in the broader category of 'culture' in this publication. I will also ask what equation Hindu culture is made to seek with the Indian nation as a whole, what social imaginary it works with, ${ }^{3}$ and what space is found for individualisation within this imaginary. ${ }^{4}$

The Gita Press was founded by two men of the Marwari merchant community. These men were responsible for its general tenor and contents both during their lifetime and after, for their works continued to be reprinted and reissued. The elder of the two, Jaydayal Goyandka (1885-1965), acted as a mentor and sage for

1 The English Kalyan-Kalpataru, started in 1934, has 100,000 subscribers.

2 The details provided in this paragraph stem from Mukul (2015), a brilliant, wide-ranging, and comprehensive study that is full of insights. It also carries a six-page account of Hindu samskriti (276-82). My paper builds upon the insights of Mukul's book but asks further questions.

3 'Social imaginary', as Charles Taylor defines it, is the 'way our contemporaries imagine the societies they inhabit and sustain' $(2004,6)$.

4 I base the use of the term 'individualisation' on the reflections provided by Martin Fuchs (2016, 105); in particular, I look for the 'attempt by social actors to fight and overcome conditions that limit or constrict them with regard to their spiritual as also political wants and needs, their search for self realisation'.

ว Open Access. ( 2019 Vasudha Dalmia, published by De Gruyter. (c) BY-NC-ND This work is licensed under a Creative Commons Attribution-NonCommercial-NoDerivatives 4.0 International License. https://doi.org/10.1515/9783110580853-053 
the younger, Hanuman Prasad Poddar (1892-1971), who served as editor of Kalyan. Together with Goyandka, he shouldered the responsibility for writing key articles for the journal and for the Press's other publications. Poddar was also the editor of Hindu Samskriti, along with Chimmanlal Goswami. ${ }^{5}$ There seems little doubt that Poddar and Goswami were instrumental in shaping the volume, although in their explanatory words at the end of the volume, they acknowledge the help of others in the editorial department of the Press. The bulk of the volume consists of concise articles by a range of Hindu thinkers, leaders, and scholars on the ancient merits and achievements of Hindu samskriti. It concludes with sections on the main gods of the Hindu pantheon, on the incarnations of these deities, on prominent ancient sages, on ideal devotees, kings, and great men, including modern politicians. It also includes accounts of some ideal Hindu women. The scope of the volume, and its effort to be as comprehensible as possible, to include the new as well as the old, makes it clear that it was a modern enterprise, and one that can claim a place of prominence in the contemporary world. ${ }^{6}$

\section{The constitution of India as counter-pole}

The timing of the publication of the volume was significant. The Constitution of India, adopted by the Constituent Assembly on November the 26th 1949, came into force in its entirety on January the 26th 1950. At this stage, the republic was defined as both 'sovereign' and 'democratic'. The addition of the words 'socialist' and 'secular' to the Preamble was a later development, brought about through a constitutional amendment in $1976 .{ }^{7}$ However, this was the direction in which Prime Minister Jawaharlal Nehru was already propelling the country.

5 He was editor of the English Kalyan-Kalpataru and became editor of Kalyan after Poddar's death, holding the post until his own demise in 1974.

6 Monika Horstman's important essay, 'Towards a Universal Dharma: Kalyan and the Tracts of the Gita Press', has made the point that the sanatana or eternal dharma propagated by the publications of the Press served the function of an ideological umbrella for modern Hinduism. The Press was critical of individual creeds and sects, even as it sought to subsume them within sanatana dharma. And finally, though it claimed to represent tradition, it was an entirely modern venture (1995, 298f.).

7 As the Preamble reads now: 'We, the people of India, having solemnly resolved to constitute India into a sovereign, socialist, secular, democratic republic, and to secure to all its citizens: justice, social, economic and political; liberty of thought, expression, belief, faith and worship; equality of status and of opportunity; and to promote among them all, fraternity assuring the dignity of the individual and the unity and integrity of the Nation; in our Constituent Assembly this twenty-sixth day of November, 1949, do hereby adopt, enact and give to ourselves this 
But this was not the only direction in which the new nation was being pushed. We have to recall that, in the early years of independence, the nation was a project very much in the making and one that stood on unsteady feet. The violence of Partition, which occured simultaneously with Independence, had torn apart the fabric of the North West and the East of the country. In addition to the countless instances of rape, maiming, and killings that happened on both sides of the border, there were now six million Hindu and Sikh refugees to resettle in India. This group provided a fertile ground for the propagation of grievances with Muslims in general. For them, as for the vast majority of Indians, the fact that Pakistan was an Islamic state seemed to demand that India too should heed its majority and become a constitutionally-backed Hindu state. On the other hand, the large segments of the Muslim population that still remained in India had also to be adequately protected from Hindu and Sikh violence, which could take virulent forms. It was just two years since Nathuram Godse, a right-wing fanatic, had assassinated Mahatma Gandhi at a prayer meeting in Delhi on January 30th 1948. Shortly before this, the Mahatma had insisted that the new Republic pay Pakistan its due share of the common Treasury. This had caused much bitterness among right-wing Hindus, many of whom saw the Mahatma as a partisan of the Muslim cause. His last fast unto death, known today simply as the Delhi Fast, had been undertaken in the days immediately preceding his assassination in order to stop the indiscriminate killing of Muslims, not only in the old city of Delhi but across India as a whole. Godse's act seemed the logical conclusion of the violence expressed against the Mahatma in Hindu quarters.

The Rashtriya Svayam Sevak Sangh (the National Volunteers Corps), although not directly implicated in the act, was active in the propagation of its vision of a Hindu India:

Realizing the Rashtriya Svayam Sevak Sangh's (RSS) adherence to the ideology of communalism and violence and the hatred that it had been spreading against Gandhi and secularism were the real forces behind the assassination - the RSS men had even celebrated it in many places - the government immediately banned the RSS and arrested most of its leaders and functionaries. Nehru, of course, had for some time been characterizing the RSS as a fascist organization. In December 1947 he stated: "We have a great deal of evidence to show that the RSS is an organization which is in the nature of private army and which is definitely proceeding on the strictest Nazi line, even following the technique of organization".

(Chandra et al. 1999, 79)

The ban was lifted in July 1949, once the RSS accepted the conditions laid down by Vallabhbhai Patel, the Home Minister. The conditions were that

Constitution'.Sourced from https://www.india.gov.in/sites/upload_files/npi/files/coi_part_full. pdf. Last accessed July the 25th, 2018. 
[t]he RSS would adopt a written and published constitution, restrict itself to cultural activities and not meddle with politics, renounce violence and secrecy, profess loyalty to India's flag and Constitution and organize itself along democratic lines.

(Chandra et al. 1999, 79)

'Culture' would become a very loaded word, masquerading for a number of political and social agendas. The experience of Partition strengthened views which pulled society in two opposing directions. At one pole was the vision of a pro-Hindu India, exemplified by groups such as the R.S.S.. The other pole was expressly secular and pluralist, determined to overcome the trauma of partition not through the elevation of one particular group but, rather, through the removal of a state religious identity.

The Committee formed to draft the Constitution was headed by Dr. Bhimrao Ramji Ambedkar, the icon of Dalit aspirations. It was Ambedkar's concept of the social order, as much as that of Jawaharlal Nehru, that guided the vision of India that was enshrined in the Constitution. As Nehru wrote in the troubled period immediately after Partition, 'I believe in India being a secular state with complete freedom for all religions and cultures and for cooperation between them. I believe that India can only become great if she preserves that composite culture which she had developed through the ages'. And in this expressly secular and pluralist social order, 'I am anxious therefore that the Muslims in India as well as all other religious groups should have the fullest freedom and opportunity to develop themselves. I am entirely hostile to Hindu or any other communalism in India' (Nehru 2003, 173, letter to the Nawab of Bhopal, July 9, 1948). As Sunil Khilnani points out,

A specifically Indian compromise was needed, and he [Nehru] saw strengths in this. That compromise was outlined in the practical adaptation, after 1947, of the state into a distinctive model shaped by Nehru's understanding of the Indian past: a model committed to protecting cultural and religious difference rather than imposing a uniform "Indianness".

(Khilnani 2004, 167)

It was a powerful and mellow vision:

In his imagination, India appeared as a space of ceaseless cultural mixing, its history a celebration of the soiling effects of cultural miscegenation and accretion, "an ancient palimpsest on which layer upon layer of thought and reverie had been inscribed, and yet no succeeding layer had completely hidden or erased what had been written previously".

(Khilnani 2004, 169)

It stood to reason, then, that the western model of the nation, with one language and one religion uniting it, could not serve for India. ${ }^{8}$

8 As pointed out by Khilnani $(2004,173)$. 
Further, the Constitution envisioned a democratic and egalitarian order with the provision of 'reservations' for the lowest castes, the 'untouchables', in government offices and educational institutions. This could not but be offensive to the vast majority of those who held the caste order to be sacred. It is against this background that, in January 1950, Hindu Samskriti was published in an effort to influence the political and cultural direction of the newly founded republic by insisting on the validity of caste hierarchy and the inherent Hinduness of India.

That the title of the volume spoke of culture rather than religion, though it placed the Hindu religion, as interpreted by it, at its core, speaks for its effort to be as comprehensive as possible. Therewith was posited a pan-Hindu culture which dominated and occupied all of India, for 'culture' includes all aspects of the person's life, aspects that would, on the face of it, fall outside the scope of religion in the narrower sense. This double move, to speak not of religion but of culture as determining the past, present, and future of Hindus, and thus of the Indian republic at large, while at the same time placing religion at the heart of this culture, is a well thought out strategy. It is followed consistently throughout the massive volume: 904 pages in small print in octavo format. It did not foreground Aryans (and we shall see below why), but insisted rather on Hindu and Hinduness. It placed a series of Vedic hymns in the original Sanskrit, with translations into Hindi, at the beginning of the volume followed by short quotations from the Upanishads, from the epics - Valmiki's Ramayana and the Mahabharata - and concluded with a brief excerpt from the Bhagavata Purana. In thus including the canonical text of the Vaishnavas - one branch of the vast family of faiths now grouped together as 'Hindu' - Hindu Samskriti, followed a pattern which was sustained throughout the volume. Religion and the social order predicated on it form the core of culture. This will become apparent as we proceed. I shall focus on three articles I consider key to understanding the propositions advanced by the volume as a whole.

The opening salvo is fired by Shankaracharya Brahmanand Saraswati of Jytorimath, Badrikashrama, in an article entitled simply 'Hindu-Samskriti' (23-32). There are five present-day Shankaracharyas, each heading his own monastery in five different corners of India. All five trace their origin to the Adi, or Ur-Shankacharya, who is thought to have lived in the ninth century CE. ${ }^{9}$ The

9 The Dakshiānmnāya Sri Sharada Peetham (main matha) at Sringeri Sharada Peetham in Shringeri, Karnataka. The Uttarāmnāya matha (Northern matha) at Jyotir Math in the city of Jyotirmath, also known as Joshimath, Uttarakhand. This is the seat of the Shankaracharya referred to above. The Pūrvāmnāya matha (Eastern matha), or the Govardhana matha at Puri, Odisha. The Paśchimāmnāya matha (Western matha), or the Dwaraka Pitha at Dwarka, Gujarat. Finally, Sarvagna Peetham Kanchi Moolāmnāya Sri kanchi Kamakoti Peetham (Sarvjna Peetham), or 
successive Shankaracharyas enjoy enormous religious authority in modern India. Depending on his particular bent and personality, a Shankaracharya can become a public figure whose stance on specific issues is given weight and prominence by the media.

The second article I shall consider is by M.S. Golwalkar (1906-1973). Golwalkar's contribution appears immediately after those of the major religious leaders of Hindu India, ${ }^{10}$ despite the fact that he was the head of that ostensibly secular force, the R.S.S., founded in 1925, at more or less the same time as the Gita Press. ${ }^{11}$ Finally, I will discuss the article on - rather than by - Mahatma Gandhi, placed two thirds of the way into the volume. The location of this article has its own significance. The question that I will ask in this chapter is, what do these contributions say about being Hindu and about individualisation in the new republic?

\section{Religion as Hindu culture}

The substantial discursive part of the volume begins with a vehemently worded article by Shankaracharya Brahmanand Saraswati of Badrikashrama. He launches into his exposition by outlining a definition of the two terms in question: 'Hindu' and 'samskriti'. He takes up the term 'Hindu' first, which he sees as a denomination of 'jati'. Jati can be translated as 'caste' and I will draw upon this usage elsewhere in the present chapter. However, here it stands rather for 'specific or generic characteristic or distinction'. ${ }^{12}$ There are two bases, the Shankaracharya says, for determining the jati of a people. They are desh or country and dharmagrantha or religious texts. The country defines how some peoples are named, thus: Germans, French, Bengalis, and Panjabis. But there is also a

the Kamakoti at Kanchipuram, Tamil Nadu. Information sourced from https://en.wikipedia.org/ wiki/Shankaracharya. Last accessed July 25, 2018.

10 Eight articles by figures from prominent Hindu religious institutions follow. These are written by the Shankaracharya of Dwarika, Karpatri Maharaj, an anonymous Mahatma, the Head of the Ramanuja Sampradya, an anonymous Mahatma of the Bharat Dharma Mahamandal, Madhavanand Maharaj (presumably the head of the Madhva Sampradaya), Aurobindo and the Mother - head of the Aurobindo Ashram in Puducherry. Aurobindo's article is translated from the English and is not written originally for the volume.

11 Anderson and Damle 1987 still remains the most detailed and reliable account of the organisation, its history, and the mode of its functioning. See also Basu et al. 1993 for a critical account of the Hindu Right.

12 Platts, John T: A Dictionary of Urdu, Classical Hindi and English (369): http://dsal.uchicago. edu/dictionaries/platts/. Last accessed on July 25, 2018. I refer to Platts throughout for the translations of Sanskrit terms I give. 
further determination by reference to the religious texts of a people, thus Christians because of their belief in the Bible or Muslims because of their belief in the Quran. On closer inspection, country proves to be an inadequate base for defining a people. Bengalis, for instance, can be Hindus or Muslims. It is the religious texts, then, that define the ultimate affiliation of a people. Jati is thus determined by religious texts rather than country or manners and customs.

Saraswati also notes the belief that there originally existed a single Aryan people who migrated to different countries and, in doing so, acquired different names. If they had all believed in the Vedas and other Shastras, then, regardless of the country in which they settled, they would have remained 'Arya' or 'Hindu'. However, some turned instead to the Bible and the Quran, proving that the primary definition of a people is not their having originally belonged together but, rather, the religious texts to which they now adhere. The Hindus (Arya is now simply dropped) are of one jati because they believe in the Vedas and other Shastras; a Hindu bases his (the reference is always male) conduct, in both this- and other-worldly contexts, on actions propagated by the srutis, smritis, Puranas, and the epics. He believes in the varnashrama order (23). More on this order below. Being Hindu is, then, based on belief in a given social order drawn from specific religious texts. This first premise makes no political or nationalist claims for being Hindu, although these will follow.

The Shankaracharya then embarks on a lengthy and involved description of samskriti, deriving it from Sanskrit roots to mean 'bhushan bhuta samyak kriti ya cheshta', that is, ornamented actions and exertions in their entirety. Samskriti enfolds all fields pertaining to cultivated activity. Of all creation, it is human activity alone that qualifies for this definition, not that of other species, for this activity leads to happiness and peace. Samskriti is further based on its philosophical texts. The questions of who I am, where I come from, where I will go, who is the creator of this universe, and so on, are all issues that are resolved by philosophy. In short, its religious and philosophical texts, which ultimately deal with the means of attaining mukti or release in this life, are the defining characteristics of a jati (25). The Shankaracharya is circling back here to his original proposition regarding the centrality of religious (philosophy is subsumed within this) texts as the defining feature of a people and their culture. The most dynamic form regarding manners and conduct of this culture is the varnashrama order, the belief in the division of Hindu society into four varnas or castes ${ }^{13}$ and in the four ashramas or stages of life $(24,26)$. This culture is auspicious and beneficiary (kalyan) not

13 These are Brahmans or priests and scholars, Kshatryiyas or warriors, Vaishyas or merchants and Shudras or servers. 
only to Hindus but to the entire universe. Following the varnashrama order makes for the most complete development, both personally and socially.

The Shankaracharya then elaborates on the four ashramas in conventional terms: brahmacharya, or celibacy in student life; grihastha, or domesticity in married life; vanprastha, or part-retirement from family and social life; and, finally, samnyasa, or asceticism towards the end of life. He offers no new insights for the adjustments presumably needed to fit these ancient notions into modern lives. This is also the case with the four-fold varna division. In Hindu samskriti, a person's jati, here meaning caste, and, consequently, his actions and professions, are decided according to birth, and thus accord with the nature with which he is originally endowed. If a person is made to follow a life pattern that differs from the one he has been endowed with, he will have to exert himself all the more, losing unnecessary energy in the process. But if all act in accordance with their place in the given social order, everything will be achieved peacefully and easily, leading naturally to societal progress in which there will be no conflict between old and new. Varnasamkarta, or the corrupting mixture of varnas, leads to the destruction of society and nation. Here we see the notion of 'nation' creeping in unannounced, for without further discussion, Hindu society has become coeval with the Indian nation at large. In fact, though, this equivalence has been inherent all along, given that it is the Hindu order alone which constitutes the nation (27). The notions of purity-impurity, touchability and untouchability, are a distinctive quality of Hindu samskriti (28). It was still politically possible to make such pronouncements in 1950; today they would need to be made more covertly.

The Shankaracharya goes on to exalt the ethical qualities that make Hindu samskriti so outstanding: respect for women, respect for the elderly, and so on, there being no space for hatred of any kind in this culture. Ultimately, he emphasises again, it is the societal division into the varnas and the stages of life that determines what constitutes Hindu samskriti. By making the belief in religious texts the centre of the definition of Hindu, the Shankaracharya explicitly excludes Christians, Muslims, and others from any form of belonging within the social order, which is universalised even as it is extended and made peculiar to all of India. Further, by speaking of the four castes as alone determining this social order, Dalits, referred to as antyaja, that is, outside the four-caste order, are placed entirely outside the Hindu social order and with that the nation.

According to the Vedas and other Shastras, temples, and the icons installed in them, are defiled by the entry of the antyaja. Ghosts and spirits enter such temples instead of divinities and the worship of these entities strengthens evil tendencies. This results in the prospering of conflict, anger, and hatred, while sickness and natural calamities, such as excessive rain, droughts, earthquakes, etc., make for the destruction of the king and his subjects (31). 
Addressing Hindus at large, the Shankaracharya proclaims: yours is the leading culture in the world. There is no worldly or otherworldly goal that you cannot attain. You have withstood the most atrocious attacks over the ages; now you need to stay firm on your path. He then takes on those in charge of the governance of independent India, asking that they oversee the creation of an order in accordance with pure Indian culture, for it is Hindu culture alone which constitutes Indian culture (29). If this does not happen in an independent India, what meaning and value would political independence have? There should be no interference in, or opposition to, the right of Hindus to follow their varnashramadharma. It is not possible to remove this order and try to set up another that is classless and casteless. This is the very least that the Hindus can expect from their own government, that their svarupa, or own form, not be attacked as if ruled by a foreign government (30).

The Shankaracharya ends by formulating seven demands of the government: that governance be moulded according to Hindu culture; that there be a law against the lowest castes entering Hindu temples, so that divine wrath not fall on all; that cow slaughter be banned; that the laws of purity and pollution not be eradicated so that the Hindu jati should not face decline; that marriage within the gotra ${ }^{14}$ and outside the varna, and divorce, etc., should not be enshrined in law; that a societal order without varna and jati not be ordained, thus undermining the Hindu order; and, finally, that the Hindu Code Bill and similar legal enactments be entirely dropped. ${ }^{15}$ The Shankaracharya closes with a prayer to the lord to save the Hindu jati.

The order that is propagated here is entirely Brahminical or as defined by Brahims, making no concessions to change and with a narrowly defined role for each citizen (always conceived of as male), one entirely derived from varnashrama. Man is straitjacketed by it; he has to follow the path laid out for him. He derives the meaning of his social existence entirely from his place in this order. He

14 A Hindu clan tracing its lineage from a common ancestor, usually a saint or a sage.

15 See Mukul (2015, 257-66) for an account of the resistance offered by Gita Press and Poddar and Goyandka to the Hindu Code Bill, on the table in the Legislative Assembly from 1944. Gita Press campaigned vociferously against it. When reintroduced in post-independence India, with Dr. Ambedkar as the Law Minister, the bill excited the same violent response. When had equality brought happiness? Inter-caste marriage, the restriction placed on polygamy, the relatively liberal laws of inheritance, adoption, would all play havoc with the system. A Hindu man could marry a low-caste girl, or a Christian, or a Muslim. Hindu women would theoretically be free to marry even Muslim men. The Indian National Congress's landslide win in the first general elections left such arguments behind, and the Hindu Code Bill was finally passed in the form of four separate bills between 1954 and 1956, much watered down but none the less promising men and women much greater flexibility than before. 
is not free to change it; he cannot, for instance, marry outside his caste without causing chaos in society.

The article is followed by a five-stanza hymn to Hindu Bharat or Hindu India by someone who calls himself simply 'Ram' (33). The hymn brings out once more what has been ostensible all through the Shankaracharya's expostulations - that Dalits, ${ }^{16}$ non-Hindus, most of all Muslims but also Christians, simply do not figure in the new republic. They are accorded no space, no rights.

In her Origins of Totalitarianism (1951), published a year after Hindu Samskriti, Hannah Arendt spoke of the German and Slavic pan-movements of the first part of the twentieth century. These movements accorded the individual a new meaning as a member of a cohesive whole and were to merge seamlessly with the agenda of totalitarian governments when the time came. What the Shankaracharya, and the mass of articles in the volume that follow in his footsteps, depicts is not unlike the goals of these pan-movements. In propagating the universal and all-comprehensive reach of Hindi samskriti, a pan-Hinduness is being posited, which swamps the rights of all non-Hindus while, at the same time, claiming divine rights for Hindus as a whole. As Arendt pointed out:

The tribalism of the pan-movements with its concept of the "divine origin" of one people owed part of its great appeal to its contempt for liberal individualism, the ideal of mankind and the dignity of man. No human dignity is left if the individual owes his value only to the fact that he happens to be born a German or a Russian; but there is, in its stead, a new coherence, a sense of reliability among all members of the people which indeed was very apt to assuage the rightful apprehension of modern men as to what might happen to them if, isolated individuals in an atomized society, they were not protected by sheer numbers and enforced uniform coherence.

(Arendt 1976, 235)

If it robs the caste-Hindu of a sense of individuality, of the freedom to disagree, to evolve his thoughts and pursuits, his sense of the self, outside of the order, it also lends him, as Arendt puts it, a sense of a new coherence, of mutual support from, and belonging among, others of his kind.

16 There are two further articles on untouchability in the volume, one dealing with why Dalits are forbidden to enter temples (214-7) and the other discussing the logic underlying this and other such practices (218). Mukul has discussed Poddar's acrimonious correspondence with Mahatma Gandhi over the latter's fast against the British award of a separate electorate for untouchables. The ideas put forward by Poddar are identical with Shankaracharya's $(2015,53-7)$. 


\section{The political-theological grid of the Hindu Right}

A different route that leads to the same sense of absolute merger and absolute affiliation is proposed by Madhavrav Sadashiv Golwalkar, the Sarsanghsamchalak, or chief executive, of the R.S.S. from 1940 to 1973. Golwalkar's contribution is also entitled 'Hindu samskriti' ${ }^{17}$ It is just four pages long but it puts forward its propositions boldly and clearly (57-61). Golwalkar is versed in the Sanskritic tradition; his language is also Sanskritic in the extreme. He is regarded as learned by his followers, hence his title 'Guruji'. Here I retrace the moves he makes and the apparent simplicity with which he proceeds to set out his argument. There are many religious paths, he says, for mankind to attain ultimate happiness. They fall into two broad groups: those that try to attain happiness by devotion to Ishvara or the lord, understanding him as the essence, and those who believe that what is apparent is the essence of the universe, seeing nothing other than this and trying to obtain the means to satisfy natural needs and desires as easily as possible. Much modern thought has taken this latter direction. However, as time passes, these paths breed dissatisfaction. There are two reasons for this. First, it is impossible to satisfy all sensory needs and it is in pursuit of the fulfilment of such needs that the most fearful wars are fought. Second, man is not without understanding (nirbuddhi). In the course of time, he understands that happiness lies not in external things nor in fulfillment of these sensory needs but, rather, in pacifying sensual desires (vasana).

It is out of this thinking and these expectations that religious paths are born. But these are paths founded on faith alone, whilst man is not able to forget the joys and sorrows of life. These religious paths seem unable to take care of the joys and sorrows of every-day life as it is lived. Man is thus faced with fearsome irresolution and this leads him to turn towards faith-less materialism. However, man also has buddhi (understanding, intellect, discernment). He searches for the ultimate reality and alights upon a range of options. The sages of ancient India have pondered upon all these. These sages understood that happiness is based not in things but, rather, in the self (atmanishtha), and that man can attain eternal peace (chirantan shanti) without any kind of material plenitude.

It is the jiva, the living Self, the vital principle or spirit, that is endowed with happiness (sukhamaya). All creation is, thus, endowed with happiness, is the manifest form (vyakta rupa) of endless truth. In addition to the jiva, the living

17 As Mukul notes, Golwalkar and Poddar admired and appreciated each others' work; Golwalkar had visited the latter in Gorakhpur $(2015,66,155 f$.). On Golwalkar's early life, his induction into the R.S.S., and his general orientation as its leader, see Anderson and Damle (1987, 41-5, 112f.). On his significance in today's India, see Bal 2017. 
Self, and the jagat, the world, there is a third point, brahma, who forms the entire mandala of the universe, pervading all while yet being apart from all and entirely independent. Experiencing the presence of this brahma is the ultimate happiness. The paths that lead to the attainment of this experience are fourfold: karma, action; bhakti, devotion; yoga; and jnana, knowledge. The jiva is himself ultimately brahma, because it is the all-pervasive brahma who manifests in the form of jiva. The vaster the jiva feels, the more happiness he attains. The 'I' and 'mine' impose limits on him. He has to abandon the slavery of these limits and become a renouncer. Golwalkar is here merely reproducing in accessible form what is familiar to most educated Hindus, in one form or another, as advaita: the monistic/non-dualistic philosophy propagated in various sophisticated schools of philosophical thought in the subcontinent at least since its first fully-fledged articulation by Shankara in the ninth century CE. But the next step Golwalkar takes is surely peculiar to his thinking.

Once renunciation has led to the obliteration of the feeling of limitedness (samkuchit bhavana), what first offers itself for consideration is a vaster entity, that is, one's own society: the nation (rashtra). The feeling emerges that the brahman who exists in the jiva, who says 'I', is manifest in a vaster form in this rashtra. Rashtra or nation is thus raised to a transcendental form. There is no question here of positing a divine origin for the Hindu nation. Much more than this, the nation is part of the brahman. Golwalkar does not seem to be speaking of nations in general when he propounds this principle but, rather, of the Hindu nation alone.

Let us pause for a moment to consider the significance of the term rashtra in Golwalkar's thinking. In his 1939 treatise, We or Our Nationhood Defined, which he later disowned, ${ }^{18}$ Golwalkar lays out his understanding of rashtra ${ }^{19}$ in a way

18 After the assassination of Mahatma Gandhi in January 1948, following which Golwalkar was incarcerated for a time, the work became authorless as Golwalkar and the R.S.S. disowned it. It has recently been reprinted by Shamsul Islam (2006, second edition 2015). Islam discusses the publication history of the work - the last of its four editions came out in 1947 (63) - showing in his introduction that although the treatise became authorless and went out of print, Golwalkar continued to think along the lines laid out therein (13-99). Jaffrelot sees this work as the charter that the R.S.S. had previously lacked (Islam 2005, 68).

19 We or Our Nationhood Defined glosses the term rashtra as follows: 'The word Rashtra, which expresses the whole of the idea contained in the English word "Nation" is as old as the Vedas and in the ancient works is described in a general way, as being so (Rashtra in truth) when it included "Swaraj" - independence, the power of the National Race over the whole land from sea to sea [...]' (Islam, 187f.). As Mukul has shown, the 1947 annual number of Kalyan opened with an extract from a speech by Golwalkar. Entitled 'Sachcha Rashtravad' or True Nationalism, the piece rails against the following blunder: 'We accepted India has many nations and like the Americans 
that, he maintains, follows the definitions of the 'learned political thinkers of the world"20:

In fine, the idea contained in the word Nation is a compound of five distinct factors fused into one dissoluble whole [,] the famous five Unities: Geographical (country), Racial (Race), Religious (Religion), cultural (Culture) and linguistic (language). ${ }^{21}$

He then considers these five factors in some detail, first in general terms and then specifically in the Hindu case. In doing so, he fuses religion and culture into one, just as the Shankaracharya had done in the preceding article. As he proclaims: 'Culture is but a product of our all-comprehensive Religion, a part of its body and not distinguishable from it' (Islam 2015, 158). ${ }^{22}$ Religion for him is not an individual question that needs to be kept out of 'public and political life'. Rather,

agreed to have a federation. This gave rise to a mutilated version of sub-nationalism in India' that 'lacks true Bharatiyata (Indianness)' (2015, 248). In June 1947, Kalyan carried another incendiary speech by Golwalkar (ibid., 253).

20 As Jaffrelot has shown, Golwalkar drew inspiration for his definition of what constitutes the nation from German thinkers, amongst others from 'Bluntsley', or Johann Kaspar Bluntschli, who defined nations as 'organic beings' with a 'national spirit' and 'national will'. The nation was not composed of an arbitrary combination of men but of those rooted in a specific civilization as articulated in the physique of the race and in their language and manners. Golwalkar's understanding of race differed from the German; it was not obsessed with purity of race but rather with common cultural traits as inherent to the group, collectively inherited from their forefathers (2005, 70-4).

21 Islam 2005, 154.

22 Golwalkar differed in his conceptions of Hindu culture and religion from that other great ideologue of the Hindu Right, Vinayak Damodar Savarkar (1883-1966), who was president of the Hindu Mahasabha from 1937 to 1943. His best-known work, The Essentials of Hindutva was published in Nagpur in 1928. Excerpts here are from the web edition of the work: http://www. savarkar.org/en/hindutva-hindu-nationalism/ essentials-hindutva. Last accessed on July 25, 2018. The overarching concept for Savarkar was culture rather than religion, which was subsumed under 'common fairs and festivals, rites and rituals, ceremonies and sacraments'. His definition of Hindu was threefold, whereby culture was defined, amidst its other attributes, by a common history, common literature, etc., rather than theologically: 'A Hindu then is he who feels attachment to the land that extends from Sindhu to Sindhu as the land of his forefathers - as his Fatherland; who inherits the blood of the great race whose first and discernible source could be traced from the Himalayan altitudes of the Vedic Saptasindhus and which assimilating all that was incorporated and ennobling all that was assimilated has grown into and come to be known as the Hindu people; and who, as a consequence of the foregoing attributes, has inherited and claims as his own the Hindu Sanskriti, the Hindu civilization, as represented in a common history, common heroes, a common literature, common art, a common law and a common jurisprudence, common fairs and festivals, rites and rituals, ceremonies and sacraments'. 
Religion in its essence is that which by regulating society in all its functions, makes room for all individual idiosyncrasies, and provides suitable ways and means for all sorts of mental frames to adopt, and evolve, and which at the same time raises the whole society as such, from material, through the moral to the spiritual plane.

Politics itself becomes a small factor 'to be considered and followed solely as one of the commands of Religion and in accord with such commands' (160). He denies the validity of sects, in short the plurality of Hindu belief systems, by proclaiming that they are 'only parts of religion' and not a multitude of religions (161). Finally, language, in the Hindu case Sanskrit, is 'an expression of the Race spirit, a manifestation of the National web of life' (162).

We can return now to Golwalkar's article in our volume. After having proclaimed the identity of this 'I' with the nation, he proceeds to further develop his proposition. ${ }^{23}$ The person becomes vast (vishal) following the identification of the individual (vyakti), society (samaj), and the world-Self (vishwatma). Bringing these three together, he experiences a vastness that is difficult to experience in this world. A philosophical-theological edifice is thus restructured to include as an integral part an entirely modern concept, samaj or society. This is further equated with rashtra or nation, as if it had existed as such since time immemorial and had integrally belonged there. Society and the nation thus acquire metaphysical dimensions.

This identification of man with nation, as Golwalkar goes on to explain it, makes for great happiness and peace in society. The people who constitute this society are of the same kind, have been created out of the same essential principle (sattattva), and therefore love one another. Society will be happy, progressive, and best (shreshtha) in the same measure as the number of knowledgeable (jnani) people who exist in it (59). By this he presumably means those who have attained a higher state and merged with the nation. To dream of 'Anarchism withering away of the state' (English in the original, 60) is possible only in Hindu culture. But while we wait for this situation to come about, Hindu culture seeks

23 As Damle and Anderson put it, Golwalkar in his Bunch of Thoughts, 'mentions four virtues that characterize the ideal man. The first is "invincible physical strength" [...] referring to the calm resolve needed for commitment to disciplined activity. The second virtue, which Golwalkar called "character", is a personal resolve to commit oneself to a noble cause. These two virtues must be guided by "intellectual acumen", the third virtue. Lastly, "fortitude" is a virtue which permits the honorable person to persevere in a virtuous life. To summarize, the virtuous life is, above all, characterized by industriousness combined with a zealous and painstaking adherence to dharma' (1987, 74; the authors have used an earlier edition of Golwalkar's work, the page numbers they give do not tally with my edition). Golwalkar remains consistent in his thinking. The adherence to dharmic norms precludes any deviance from them, readying the individual for his merger with the nation. 
to regulate matters, to provide a corrective to disorder and misrule. Hindu culture and social order are here made coeval with the state without any further discussion. Non-Hindus are obviously excluded from this order, since the same fellow feeling and love cannot exist outside the religion which fuses them together.

Hindu culture has sought to provide an order to curtail the injustice perpetrated by those with wealth on those without wealth. This is the first and only mention of social inequality; it is immediately countered. For Hindu culture has seen that mutual dependency, mutual cooperation, fellow feeling, and affection are what keep society well ordered. Hindu culture has sought to follow this principle in the constitution of its social order (60).

Golwalkar concludes by reverting to his central thesis: 'In everyday (vyavaharik) life, all people should follow the resolve (dharana) that this society is the manifest form of the incorporeal Highest Self (amurta paramatma)'. This Highest Self is the lord of the world.

The individual, becoming vast, in order to attain this happiness-filled (sukhamaya) Highest Self, has the duty to serve this manifest form of the Highest Self by becoming one with it, by renunciation, by selflessness, with his body, mind and speech, by offering it body, mind and wealth. Only by fulfilling this duty with his entire feeling (sarvabhava), can he attain success in this life, can attain happiness.

The wise who practice this Hindu culture will see that only this will lead to world peace and they will light the path for those who have forgotten their culture. Golwalkar closes by offering his short article at the feet of the Highest Self in the form of the Hindu nation (61).

This idea of the individual as part of a whole is repeated incessantly in Golwalkar's writings, though elsewhere less explicitly clothed in a theological edifice than in the above formulation. Expressed in more general terms, which are of some significance for our considerations here, he says in the translated version of his writings compiled under the title Bunch of Thoughts:

In the same manner, individuals, though imperfect, when merged into a corporate whole, can give rise to a perfect society. And therefore the superficial differences born out of the imperfections of the individuals are only indicative of the diverse manifestations of the one great and perfect and mighty reality - the society. This appreciation of the inherent spark of Truth, of Divinity in every individual, has penetrated into our various components and spheres of life - religious, social, political and economic - and patterned them for a harmonious pattern of mutual goodwill and respect. This catholicity of spirit is an altogether unique contribution of our culture to world thought.

(Golwalkar 1980, 51f.)

As Golwalkar puts it a little later in Bunch of Thoughts: 'The 'permanent', therefore, is the national life. The 'impermanent' is the individual' (61). This, then, is 
a consistent pattern of thinking: national life is identified with the transcendent Highest Self, or Ultimate Reality, and the individual is asked to merge with this national life in order to acquire perfection and permanence. ${ }^{24}$ Once again, Hannah Arendt provides a crucial insight into the kind of thinking that underlies pan-movements such as this:

The pan-movements preached the divine origin of their own people as against the Jewish-Christian faith in the divine origin of Man. According to them, man, belonging inevitably to some people, received his divine origin only indirectly through membership in a people. The individual, therefore, has his divine value only as long as he belongs to the people singled out for divine origin. He forfeits this whenever he decides to change his nationality, in which case he severs all bonds through which he was endowed with divine origin and falls, as it were, into metaphysical homelessness. The political advantage of this concept was twofold. It made nationality a permanent quality which no longer could be touched by history, no matter what happened to a given people - emigration, conquest, dispersion. Of even more immediate impact, however, was that in the absolute contrast between the divine origin of one's own people and all other nondivine peoples, all differences between the individual members of the people disappeared, whether social or economic or psychological. Divine origin changed the people into a uniform 'chosen' mass of arrogant robots.

(Arendt 1976, 233f.)

Golwalkar takes the hierarchical thinking of the Shankaracharya, and the bulk of the articles in the volume that echo him, to another level of abstraction, in which varna, the social status one is born into, is to be considered natural and innate to the person. The ground reality can be whatever it is; he leaves it untouched and uncritiqued. In Golwalkar's thinking it becomes irrelevant. He does not address any notion of social inequality, any question of social injustice. The same is true of all sense of individuality. Difference of personhood is considered superficial, a sign of imperfection. Individuality is regarded as something that needs to be submerged into a greater whole to achieve its potential, into samaj or Hindu rashtra. This is but one step towards a yet greater whole, paramatma or the Highest Self, making the rashtra or nation part and parcel of a transcendence that is absolute, unreachable by history.

What of those who are not Hindus? In his 1939 book, the author who then identified himself as Golwalkar maintained roundly that,

all those, who fall outside the five fold limits of the idea [nation], can have no place in the national life, unless they abandon their differences, adopt the religion, culture and language of the Nation and completely merge themselves in the National Race.

(Islam 2015, 181)

24 Jaffrelot also makes this point briefly: 'This ideologically based cohesion coincides with a devaluation of individuality in the R.S.S.; the "new man" must sacrifice his personality to the cause' $(2005,79)$. 
As long as they maintain their difference, they are foreigners and live at the mercy of the national race. They 'may stay in the country, wholly subordinated to the Hindu Nation, claiming nothing, deserving no privileges, far less any preferential treatment - not even citizen's rights' (Islam 2015, 183f.).

As in the view of the Shankaracharya, the social and cultural order proposed by Golwalkar as the base of the Hindu nation is Brahminical in its terminology as much as in its orientation. As Jaffrelot has pointed out, although the R.S.S. was conceived of as egalitarian, the view of its leaders continued to be based in the varna system, its pracharaks or preachers being drawn overwhelmingly from the Brahmin caste. The appeal to the low castes was surely in part due to the process of Sanskritisation, or the upward social mobility that belonging to this order entailed. ${ }^{25}$

To return to the Gita Press volume, the universal impact of Hindu culture on other cultures is proclaimed by no less a personage than C. Rajagopalachari (1878-1972), the then Governor-General of India (1948-1950), in his one page article. It is titled 'Hindu samskrit hi vishvasamskriti hai' or 'Hindu culture alone is world culture' (63). As far as Rajagopalachari is concerned, there is no question of mutual interaction with other cultures; the action is entirely one-way. The universalistic claims of Hindu culture are maintained also by two historically sketchy articles in the volume which deal with the influence of Hindu religion and culture on Islam and Sikhism, written, respectively, by a Muslim, Saj Rehmani 'Firdausi Baba', and a Sikh, Gyani Santsingh Pritam. These articles are intended as evidence that Rajagopalachari's proposition is accepted by the followers of these two religions.

In the concluding section of this essay, I turn to the treatment in the volume of Mahatma Gandhi, who identified himself as a believing Hindu through his life and who was arguably the most significant Hindu of his time. Two thirds of the way in, the Gita Press volume contains a five-page article on 'Mahatma Gandhi aur hindu samskriti', 'Mahatma Gandhi and Hindu culture', by Pandit Lakshminarayan Garde, a member of the editorial department of the Press and of the editorial board of our particular volume. ${ }^{26}$ This article is sandwiched between an article on death rites in Hindu culture and a set of three articles on the place of the cow, and on its protection, in Hindu culture. The Mahatma's thinking is presented largely in accordance with the general editorial bent of the volume, though his marked deviations from it are impossible to entirely ignore and are

25 Savarkar differed from those who believed in preserving the purity of the caste system. He believed in cross-caste marital unions.

26 Ibid. 598-604. As Mukul has noted, the Kalyan did not register the assassination of the Mahatma in its February 1948 issue. In fact, Poddar was actively involved in defending the R.S.S., which, as noted above, had been banned for its alleged role in the killing $(2015,58 \mathrm{f}$.). 
partially noted. In the following, I present the main points of the article. I then go on to discuss how the Mahatma's deeply personalised moral vision, his radical reformulation of views he held earlier, is essentially either not realised and registered or is passed over deliberately in this account.

\section{Gandhi's vision as second counter-pole}

Garde begins by proclaiming that Hindu samskriti itself was incarnated in the person of Mahatma Gandhi. The Mahatma was proud to be a Hindu. He proclaimed himself a sanatani or eternal Hindu. ${ }^{27}$ There was no trace of communalism in his thinking, and Garde draws from this the conclusion that Gandhi was proof of the fact that the Hindu is, in general, not communal; he has love for all in his heart. The Mahatma's universal love manifested itself in his dharma to free India. He showed by his work in South Africa that there was no feeling of enmity in his heart (598). Garde cites an excerpt from an interview with an English journalist at the beginning of 1937 as evidence that the Mahatma had full faith in his god that India would win its independence from the British, a belief that was fulfilled on August 15th 1947. This belief in God is the root base of Hindu culture, from which originates the second base, religion (599). Once again, we see that the wider term 'culture' envelopes the more particular 'religion'.

Garde follows these propositions with a second, partial quotation from the Mahatma. In this very early quotation, from Young India, September 29th 1920, Gandhi makes four declarations: that he believes in the Vedas, Upanishads, Puranas and all Hindu religious texts; that he believes in varnashrama dharma; that he believes in cow protection; and that he does not disbelieve in the worship of murtis or icons. Garde adds that the Mahatma did not believe in socialism or communism. His was a belief in religion, in ishvara, the lord, and in the traditionalism of Hindu samskriti. Having proclaimed this, Garde is forced to make important admissions on the grounds of the Mahatma's later radical qualifications of his early statements, though he treads with great caution while doing so.

27 'Sanatana Dharma' or eternal, perpetual Dharma, to which most mainstream modern Hindus see themselves as belonging, is a nineteenth century creation. It projects itself as monolithic, pan-Hindu, and as enshrined in the oldest texts of the Hindus. As Zavos has pointed out in the context of the Sanatana Dharma Sabhas or Associations that sprang up from the late-nineteenth century in response to reform movements, practice and structure (image worship and caste hierarchies) - as opposed to a theological core - were propounded as the defining features of this dharma (2000, 50-7). The Mahatma, in fact, does not fit into this mould, as we will see. The others represented in Hindu Samskriti do. 
There were certain things in Gandhism, he explains, that, in the eyes of the sanatani Hindus, were not in accordance with the Shastras, the institutes of religion. However, despite thus deviating, the Mahatma continued, from his own perspective, to base his views in Hindu samskriti. For example, although he believed in the varna order, he did not observe the present rules regarding commensality or inter-caste marriage. Nevertheless, he agreed in principle that marriages work best within one's own culture. And although his effort to improve the lot of the lower castes and to promote Hindu-Muslim unity will always remain praiseworthy, if a person knowledgeable in the Shastras were to proclaim these beliefs to be outside the realm of these institutes, his saying so would not be out of place. Garde then quotes the Mahatma as saying that the store of Hindu samskriti is as overflowing as nowhere else in the world, something that the people do not yet know, as they have been kept far from it and have not yet recognised its virtues. As Garde proclaims, it is thanks to the British that they have forgotten their own cultural wealth (600).

This is followed by general observations on the decentralised economic order that the Mahatma wanted to see established, the dismantling of large industrial units, and his regard for honesty in public transactions, all of which were patently being disregarded in newly independent India. The socialism that was being followed was not in accord with Hindu samskriti (601). This was happening because Hindus were turning away from god, from the Mahatma's belief in the Bhagavadgita. However, the Mahatma also used the Muslim terms for god Rahim, Karim, and Allah - to persuade Muslims to acknowledge god, although it was unclear what effect this would have had on them (602). The rest of the article deals at length with the Mahatma's own emphasis on the significance and value of chanting the name of Rama, and the crises from which this chanting had saved him (603). Garde closes with the observation that it was through this belief in the name of Rama that God procured independence for India. This independence should be used today in the cause of Rama. Only then would it be protected and prosper, leading to the spread of the rule of Rama throughout the world. The Hindu religion is then to rule the world as much as the nation.

With the exception of his two equivocations concerning Dalits and Muslims, Garde presents the Mahatma's thinking rather schematically in an effort to contain him. He does not falsify so much as omit or suppress that which does not fit into his generally conservative view of the Mahatma, although he does note where the Mahatma falls entirely out of line with the normal trends of conservative Hindu thought. It is important to see what aspects of the Mahatma's thought he leaves out and ignores in order to make clear what he cannot afford to entertain as worthy of note - the issues which would question the central ideas of the volume as a whole. 
The Mahatma's key ideas were evolved over time as part of his active life and they can often seem contradictory when taken out of chronological order. In order to understand his notion of Hinduism, I have mostly relied on the meticulous work of J.T.F. Jordens (2012). Jordens' interpretation, while taking cognisance of key studies of the Mahatma's life and works, relies almost exclusively on the Mahatma's own writings in laying out his views on the most salient aspects of his beliefs. Jordens pays particular attention to the changing of these views over time, for the Mahatma often revised his own earlier opinions. He was not apologetic about this. Jordens cites his proclamation that,

"I have never made a fetish of consistency", and [he] advised the reader to reject his earlier statements for his later ones.

(Jordens 2012, 108, citations from The Collected Works of Mahatma Gandhi, henceforth CW, vol. 59, 62).

According to Jordens, the two most balanced statements of the Mahatma's views of Hinduism were published in 1921, the first in Gujarati in Navajivan under the title 'Who is a Sanatani Hindu?', and the second later in the year in English in Young India, under the title 'Hinduism'. The Mahatma affirmed the fundamental tenets of Hinduism; a Hindu was one who believed in the existence of the atman, the Self, and the paramatman, the Highest Self; who believed that the atman did not go through birth and death but passed from existence to existence; and who believed that the atman could attain moksha or release from this cycle. He also dealt in these writings with the question of revelation. As he wrote in the English article, he had deliberately omitted the words 'divine revelation' with regard to the Vedas as he did not believe in the exclusive divinity of the Vedas. The Bible, the Koran, and the Zend Avesta were also divinely inspired. Secondly, not every word and every verse of these texts was divinely inspired. These had to pass the test of reason and morality before they could be accepted as true. And finally, he repudiated the authority, if they claimed it, of the 'present Shankaracharyas and shastris to give a correct interpretation of Hindu scriptures'. People capable of doing so could emerge in the future but, in the meantime, 'we, the common people, may cling to the essentials with a simple faith and live our lives in bhakti to God' (ibid., 88-90; the Mahatma's statements from $C W 21,246)$. This repudiation of the claim of the Vedas to be the sole divine revelation, and of the authority of the Shankaracharyas and other religious leaders to interpret them, contradicts in its entirety all that is represented as Hindu Samskriti in article after article of the Gita Press's publication. We should also to note that, in his later years, the Mahatma took care to distinguish between religion and culture, as Kumkum Sangari has shown. Regional and professional commonalities, shared 
customs and languages, common suffering in the context of colonial domination, and the struggle for independence, all of these undercut religious difference (Sangari 2002, 8f.).

As for the belief in varna and ashrama, the Mahatma held to their basic validity all his life. But if he had originally claimed that they exercised beneficial restraints for promoting self-control, he later modified his opinion radically with regard to intermarriage and interdining, as Garde had also pointed out. Lack of restraint in these matters, according to the Mahatma, had lead to the creation of innumerable jatis, which had created chaos. The original varna scheme had placed no restriction on intermarriage and interdining, which had now been brought into operation. It was necessary now to revert to the original order:

The law of varna has nothing to do with these restrictions. People of different varnas may intermarry and interdine....But a Brahmin who marries a Shudra girl or vice-versa commits no offence against the law of varna.

(Jordens 2012, citations from The Collected Works of Mahatma Gandhi, henceforth CW)

By 1931, he had declared that according to his definition of varna, 'there is no varna in operation in present day Hinduism'. It had become extinct. By 1933 he was declaring both intermarriage and interdining to be a personal matter.

His writings on the issue of untouchability are voluminous. As he stressed again and again, he was vehemently and expressly opposed to the doctrine and denied that it was sanctioned by scripture:

If I discovered that those scriptures which are known as Vedas, Upanishads, Bhagavadgita, Smritis, etc. clearly showed that they claimed divine authority for untouchability [...] then nothing on this earth would hold me to Hinduism. I should throw it overboard as I should throw overboard a rotten apple.

(Jordens, 112f., citation from $C W 57,7$ )

Untouchability was contrary to reason; it was a violation of truth and of nonviolence. And it was in conflict with the fundamental precepts of Hinduism (ibid., 112f., CW 26, 265). We have seen above that the Shankaracharya saw the practice of denying temple entry to Dalits as not only in consonance with varnashrama dharma but also in keeping with the natural order of the cosmos, prophesying dire natural disasters if it was transgressed.

In the present context, three further issues warrant a closer, if necessarily brief, look. First, the Mahatma's insistence in his last years that religion was a personal rather than a political matter, that it could never be a state concern: 'Religion is a personal matter which should have no place in politics' (Sangari 2002, 4; citation 
CW 76, 402, from the Mahatma's paper, Harijan, 9 August 1942). As he specified in another context:

I do not believe in State religion even though the whole community has one religion. State interference will probably always be unwelcome. Religion is purely a personal matter. There are in reality as many religions as minds. Each mind has a different conception of God from that of another.

(ibid., 6, citation from Harijan, 16 March 1947, CW not specified)

Secondly, we need to take note of the intensely personal nature of his moral vision. As Jordens points out, 'in the final instance the supreme authority in matters religious is vested in the individual conscience. This primacy has been given the name of "the inner voice" by Gandhi' (Jordens 2012, 152, citation CW $26,140)$. To safeguard against capricious use of it, the Mahatma at various times specified under what conditions it could be held to be valid:

We should listen to everybody's advice, but do only what our conscience tells us. And in order that our conscience may speak, we should observe the yama-niyamas [rules and regulations for the spiritual aspirant similar to the Ten Commandments]. Everybody cannot hear the inner voice. We need divine ears to hear it.

(Jordens 2012, 153, citation CW 49, 311)

In speaking of the decision to embark on his 1932 Poona fast in his fight against the communal award of separate electorates to Dalits in response to hearing the inner voice, he spoke once again of the preparation needed in order to hear it:

Realist things are only relatively so. For me the Voice was more real than my own existence. It has never failed me, and for that matter, anyone else. And everyone who will can hear the Voice. It is within everyone. But like everything else, it requires previous and definite preparations.

(Jordens 2012, 144)

The point to be made here is the radical individuality of his moral vision. It stands in sharp contradiction to the primacy given to the authority of texts as propagated by the Shankaracharya and the other contributors to the volume.

Finally, it will be worth considering the Mahatma's ideas on pluralism, which he put forward in his later years, modifying his earlier views about the supremacy of Hinduism over other religious systems. Jordens once more: 'in his writings after 1930 no single statement can be found affirming or even suggesting the superiority of Hinduism, which he had repeatedly referred to before that date' (Jordens 2012, 166). The change was deliberate and, according to Jordens, can be dated to a letter written to Narandas Gandhi on the 23rd of September 1930:

Equality of Religions. This is the new name we have given to the Ashram observance which we know as "Tolerance" [...] I did not like the word but could not think of a better one. 


\begin{abstract}
Kakasaheb, too, did not like the word. He suggested "Respect for all religions". I did not like that phrase either. Tolerance may imply a gratuitous assumption of inferiority of other faiths to one's own and respect suggests a sense of patronising, whereas ahimsa teaches us to entertain the same respect for the religious faith of others as we accord to our own, thus admitting the imperfection of the latter.

(ibid., 165; citation $C W 44,166$ )
\end{abstract}

It has been necessary to devote considerable space to the Mahatma's views in order to set into sharper relief the views expressed in the two leading articles of our Gita Press volume, which the mass of other articles in, and contributions to, the special issue on Hindu samskriti follow and confirm in their own ways. The Mahatma differed in all key aspects from them: in the matter of religion and culture being one, in acknowledging the absolute authority of the Vedic corpus or the authority of religious leaders as sole interpreters of it, in the belief in the inviolability of the varna order and in the legitimacy of untouchability. He regarded religion as a personal matter: there were as many religions as minds, it was certainly not a political concern, and there could be no legitimate state religion. And, finally, he differed from them in his belief in pluralism. These views and beliefs the Gita Press volume obliterated entirely in its effort to offer an authoritative and cohesive view of Hindu culture, compounded as it was of a range of similar positions. The Shankaracharya and Golwalkar held identical views on the superiority of the all-pervasive culture of Hindus in India, rooted in their religion and philosophy, as laid down in their canonical texts in Sanskrit. Being Hindu meant adhering to these texts. Their mental make up as part of the varna order, their common culture and religion, bound all Hindus together; there could be no difference amongst them. They alone constituted the nation. There could be no space for individual Hindus to form themselves meaningfully outside this scheme of things. Neo-traditionalisation had won the day.

\title{
References
}

\section{Online sources}

Platts, John T. A Dictionary of Urdu, Classical Hindi and English, http://dsal.uchicago.edu/ dictionaries/platts/ (last accessed on July 25th, 2018)

Savarkar, Vinayak D. The Essentials of Hindutva, http://www.savarkar.org/en/hindutva-hindunationalism/essentials-hindutva (last accessed on July 25th, 2018)

Shankaracharya, https://en.wikipedia.org/wiki/Shankaracharya (last accessed July 25th, 2018) The Constitution of India, https://www.india.gov.in/sites/upload_files/npi/files/coi_part_full. pdf (last accessed July 25th, 2018) 


\section{Printed sources}

Anderson, Walter K. and Shridhar D. Damle. 1987. The Brotherhood In Saffron: The Rashtriya Swayamsevak Sangh And Hindu Revivalism. Delhi: Vistaar Publications.

Arendt, Hannah. 1976. The Origins of Totalitarianism. San Diego/New York/London: Harcourt Brace Jovanovich.

Bal, Hartosh Singh. 2017. 'The Instigator: How MS Golwalkar's virulent ideology underpins Modi's India', Caravan. 31-45.

Basu, Tapan et al. 1993. Khaki Shorts and Saffron Flags: A Critique of the Hindu Right. Hyderabad: Orient Longmans.

Chandra, Bipan, Aditya Mukherjee and Mridula Mukherjee. 1999. India after Independence. New Delhi: Viking.

Fuchs, Martin. 2016. 'Processes of religious individualisation: stocktaking and issues for the future'. In First Results of the Second Funding Period of the Research Group Religious Individualizations in Historical Perspective (2013-2015): A Reader, Erfurt: University of Erfurt, Max Weber Center, 97-115.

Gandhi, Mohandas K. 1958-1982. The Collected Works of Mahatma Gandhi. 90 vols. New Delhi: Publications Division, Ministry of Information and Broadcasting.

Golwalkar, Madhav S. 1980. Bunch of Thoughts. Bangalore: Jagarana Prakashana.

Horstmann, Monika. 1995. 'Towards a Universal Dharma: Kalyan and the Tracts of the Gita Press'. In Representing Hinduism: The Construction of Religious Traditions and National Identity, eds. Vasudha Dalmia and Heinrich von Stietencron, Delhi/Thousand Oaks/ London: Sage. 294-305.

Islam, Shamsul. 2015. Golwalkar's We or Our Nationhood Defined. A Critique with the Full Text of the Book (scanned from the original 1939 edition). Delhi: Pharos.

Jaffrelot, Christoph 2005. 'The R.S.S.: A Hindu Nationalist Sect'. In The Sangh Parivar: A Reader; ed. idem; Delhi: Oxford University Press. 56-102.

Jordens, J.T.F. 2012. Gandhi's Religion: A Homespun Shawl. Delhi: Oxford University Press. Khilnani, Sunil. 2004. The Idea of India. Delhi: Penguin Books.

Mukul, Akshaya. 2015. Gita Press and the Making of Hindu India. Noida: HarperCollins.

Nehru, Jawaharlal. 2003. The Essential Writings of Jawaharlal Nehru. vol 1. eds. Sarvepalli Gopal and Uma lyengar. Delhi: Oxford University Press.

Poddar, Hanumanprasad and Chimmanlal Gosvami (eds.). 1950. Kalyan. Hindu Samskriti Amk. Gorakhpur: Gita Press.

Sangari, Kumkum 2002. 'A Narrative of Restoration: Gandhi’s Last Years and Nehruvian Secularism', Social Scientist 30.3-4. 3-33.

Taylor, Charles. 2004. Modern Social Imaginaries. London/Durham: Duke University Press. Zavos, John. 2000. The Emergence of Hindu Nationalism in India. Delhi: Oxford University Press. 